\title{
Paul J. du Plessis, Studying Roman Law, Bristol Classical Press, London 2012, 125 stron
}

Prezentowana praca wykładowcy School of Law, University of Edinburgh, ukazała się w ramach Classical World Series. Zgodnie ze słowami autora wyrażonymi w przedmowie, napisana została głównie jako krótki przewodnik dla tych wszystkich, którzy chcieliby uzyskać podstawową wiedzę na temat rzymskiego prawa prywatnego w okresie pierwszych trzech stuleci naszej ery. Paul J. du Plessis podkreśla wyraźnie, że książka nie powinna być traktowana w kategoriach opracowania zastępującego podręcznik do prawa rzymskiego. Ma jedynie charakter wprowadzający i z tego względu nie zawiera w swojej treści szczegółowych opisów licznych, mocno skomplikowanych kwestii natury prawnej. Obszar omawianych przez autora zagadnień stanowią stosunki między osobami w zakresie spraw rodzinnych i majątkowych, czyli rzymskie ius privatum. To ono bowiem, $\mathrm{z}$ uwagi na istotną rolę, jaką odegrało i nadal odgrywa w formowaniu się współczesnego prawa prywatnego wielu państw, przyciąga największe zainteresowanie zarówno tych, którzy ex professo zajmują się prawem antycznego Rzymu, jak też studentów (w znacznej mierze wynika to jednak z konieczności złożenia egzaminu z prawa rzymskiego) oraz prawników praktyków, dla których znajomość pojęć, instytucji czy reguł prawnych ukształtowanych przez starożytnych Rzymian okazuje się pomocna w ich pracy zawodowej. Studying Roman Law ma zatem dostarczyć czytelnikom elementarnych wiadomości o prawie rzymskim w okresie jego szczytowego rozwoju i tym samym zachęcić ich do sięgnięcia po bardziej specjalistyczne pozycje naukowe.

Zasadniczą część pracy tworzą cztery rozdziały traktujące kolejno o: źródłach i metodach periodyzacji prawa rzymskiego (Sources and methods, s. 13-35); prawie dotyczącym osób (Persons, s. 36-54); prawie odnoszącym się do rzeczy (Things, s. 55-108), w ramach którego wyróżniono trzy podrozdziały poświęcone zagadnieniom związanym z własnością (Property, s. 56-72), zobowiązaniami (Obligations, s. 72-101) i dziedziczeniem (Succession, s. 102-108), oraz prawie dotyczącym skarg (Actions, s. 109-119). Ponadto w opracowaniu znalazło się również chronologiczne zestawienie okresów panowania poszczególnych cesarzy wraz ze wskazaniem najważniejszych wydarzeń historycznych, regulacji prawnych, jak też zdarzeń mających kluczowe znaczenie dla rozwoju rzymskiej myśli prawniczej okresu klasycznego (Timeline, s. 6-10), następnie przedmowa (Preface, s. 11), wykaz stosowanych skrótów (Translations and Abbreviations, s. 12), bibliografia (Bibliography, s. 121-122) oraz wspólny indeks rzeczowy, osobowy i nazw geograficznych (Index, s. 123-125).

Pojawienie się na rynku wydawniczym opracowania, którego celem jest zachęcenie jak najszerszego grona czytelników do bardziej pogłębionych studiów 
nad prawem rzymskim należy przyjąć z radością. Myśl prawnicza starożytnych Rzymian jest obok filozofii greckiej i chrześcijaństwa jedną z tych dziedzin kultury antycznej, które wywarły szczególny wpływ na kształtowanie się duchowego i kulturalnego oblicza Europy. Nie powinna być ona zatem przedmiotem zainteresowania niemal wyłącznie romanistów i słuchaczy wydziałów prawa. Ius Romanum stanowi bowiem pomnik wiedzy i kultury prawnej o nieprzemijającej wartości i bez wątpienia zasługuje na to, by przyciągnąć uwagę znacznie większej liczby czytelników.

Praca P. J. du Plessisa z całą pewnością może skłonić osoby niemające wcześniej styczności z prawem rzymskim do sięgnięcia po bardziej specjalistyczne opracowania. Autor prezentuje wybrane zagadnienia w bardzo przystępny sposób. Omawianie poszczególnych kwestii natury prawnej ilustrowane jest licznymi tekstami źródłowymi, zaczerpniętymi przede wszystkim z Instytucji Gaiusa i Digestów justyniańskich, ale wykorzystywane są też źródła papirologiczne. Przedstawianie szeregu instytucji prawnych antycznych Rzymian opatrzone jest zazwyczaj jasnym komentarzem, stąd prawidłowe zrozumienie poruszanej problematyki nie nastręcza większych trudności. Generalnie publikację należy ocenić pozytywnie ${ }^{1}$. Uważna lektura pracy pozwala co prawda dostrzec pewne jej niedoskonałości, ale ich obecność nie zmienia jednak ogólnego, dobrego wrażenia recenzowanego dzieła.

Pierwszy rozdział pracy rozpoczyna autor od prezentacji powszechnie przyjętego przez romanistów podziału rozwoju prawa rzymskiego na cztery okresy oraz wyjaśnienia, dlaczego zasadniczą uwagę skoncentrował na omówieniu okresu prawa klasycznego. Uważa także za stosowne przedstawienie krótkiej charakterystyki pozostałych okresów w historii źródeł iuris Romani, co pozwoli sięgającym po opracowanie spojrzeć na prawo starożytnych Rzymian w znacznie szerszym kontekście. Paul J. du Plessis zdecydowanie najwięcej miejsca poświęca jednak okresowi prawa klasycznego, który, jak sam zaznacza, „represents the high point of Roman legal development” (s. 21). Autor analizuje kolejno główne źródła prawa w tym okresie, do których zalicza: ustawy uchwalane przez zgromadzenia ludowe, edykty ogłaszane przez pretorów, prawotwórczą działalność jurystów i konstytucje cesarskie. Nie odniósł się natomiast, chociażby w skromnym zakresie, do uchwał podejmowanych przez senat (senatus consulta), choć aż pięć z nich przywołuje w Timeline jako Legally significant development.

Lektura przekazanych przez autora treści pozwala stwierdzić, iż poszczególne zagadnienia przedstawione zostały w dosyć interesujący sposób. Niektóre ze sformułowań budzą jednak niepokój. Otóż wzmiankując konstytucję cesarską z 212 roku, nadającą ludności zamieszkującej Imperium Romanum oby-

1 Rec. P. Mitchell, [z:] P. J. du Plessis, Studying Roman Law, „The Classical Review” 2013, nr 2, s. 533-534 . 
watelstwo rzymskie i znaną jako Constitutio Antoniniana, przeczytać można, iż wydana została przez cesarza Antoninusa Piusa (s. 21). Wspomnianą konstytucję ogłosił jako edictum oczywiście cesarz Karakalla, co na szczęście zauważa autor w dalszej części pracy (s. 36).

Niestety, na nieco poważniejsze niedociągnięcia czy wręcz błędne informacje natrafić można także $w$ innych miejscach opracowania. Omawiając prace nad redakcją Digestów justyniańskich autor pisze: „A commission of seventeen men was instructed to review the books of thirty-eight jurists of the classical period. These were the most important jurists of their day, awarded the ius respondendi (the right to give authoritative responses) during their lifetime. Gaius was one of them" (s. 30-31). Z cytowanego tekstu wynika wyraźnie, że w opinii P. J. du Plessisa Digesta zawierają fragmenty pochodzące wyłącznie z pism 38 jurystów okresu klasycznego. Nie wspomina on jednak ani słowem, że na zawartość tego słynnego dzieła składają się również wyciągi z prac prawników okresu przedklasycznego (Aeliusa Gallusa, Quintusa Muciusa Scaevoli pontifexa i Alfenusa Varusa) oraz okresu poklasycznego (Hermogenianusa i Arcadiusa Charisiusa). Co więcej, na podstawie powyższego fragmentu czytelnicy mogą wnioskować, że Gaius otrzymał przyznawany przez cesarzy okresu klasycznego wybitnym jurystom przywilej udzielania autoryzowanych odpowiedzi na pytania natury prawnej (ius respondendi ex auctoritate principis). Tymczasem według dominującego $\mathrm{w}$ romanistyce poglądu jurysta ten nie był postrzegany przez współczesnych mu znawców prawa jako autorytet naukowy i nie cieszył się wspomnianym wyróżnieniem². Być może wykładowca University of Edinburgh prezentuje odmienne stanowisko w tej kwestii, ale jeśli rzeczywiście tak jest, to powinien o tym napisać.

Swoje rozważania w omawianym rozdziale P. J. du Plessis zamyka kilkoma uwagami na temat przydatności literatury łacińskiej w poznaniu klasycznego prawa rzymskiego. W jaki jednak sposób spuścizna literacka żyjącego w latach 106-43 p.n.e. Cycero przyczynić się może do wzbogacenia naszej wiedzy o praktyce prawnej tego okresu, pozostanie już chyba tajemnicą samego autora (s. 34). Pochodzący z Arpinum mówca, filozof i polityk pozostawił nam wiele niezwykle cennych informacji, ale nie mógł antycypować pewnych wydarzeń.

Problematykę prawa dotyczącego osób otwierają rozważania na temat sytuacji prawnej niewolników. Autor wzmiankuje o formalnych i nieformalnych sposobach ich wyzwalania, choć nie podaje, jak w praktyce owych wyzwoleń dokonywano (s. 39-40). Traktując o małżeństwie w prawie rzymskim, P. J. du Plessis wspomina o wymogach do jego zawarcia, poświęca także kilka

2 Gaius, Instytucje, z języka łacińskiego przełożył i wstępem opatrzył C. Kunderewicz, opracował J. Rezler, Warszawa 1982, s. 6; Gai Institutiones. Instytucje Gaiusa. Tekst i przekład, z języka łacińskiego przełożył, wstępem i uwagami opatrzył W. Rozwadowski, Poznań 2003, s. XII. 
zdań kwestiom związanym z posagiem. Dzieli się spostrzeżeniami na temat rozwiązania węzła małżeńskiego $\mathrm{w}$ drodze porozumienia się stron, jak też podjęcia takiej decyzji tylko przez jedną z nich. Uwadze autora uszedł jednak fakt, że matrimonium $\mathrm{w}$ prawie antycznego Rzymu ustawało również na skutek doznania przez jednego z małżonków największego (capitis deminutio maxima) bądź też średniego uszczuplenia praw jednostki (capitis deminutio media). Zabrakło także choćby skromnych odniesień do konkubinatu, który był przecież najbardziej rozpowszechnionym związkiem pozamałżeńskim w cesarstwie rzymskim. Pisząc o wygaśnięciu władzy ojcowskiej (patria potestas) autor ogranicza się do wskazania takich przyczyn, jak śmierć zwierzchnika rodziny i emancypacja (s. $43^{3}$ i $53^{4}$ ). Milczeniem pomija zaś inne okoliczności, na skutek których pater familias tracił władzę nad podległymi mu osobami. Wskazać tu można capitis deminutio media po stronie sprawującego władzę ojcowską bądź też zaistnienie takiej sytuacji po stronie osoby podlegającej władzy naczelnika rodziny (G. 1, 128). Patria potestas wygasała także w przypadku wyboru synów na najwyższe urzędy kapłańskie lub wstąpienia córek do kolegium westalek (G. 1, 130).

Odnosząc się do literatury zaproponowanej przez autora wydaje się, że warto byłoby $w$ kontekście prawa dotyczącego osób wymienić jeszcze następujące prace: W. W. Buckland, The Roman Law of Slavery. The Condition of the Slave in Private Law from Augustus to Justinian (Cambridge 1908); A. Watson, Roman Slave Law (Baltimore 1987); P. E. Corbett, The Roman Law of Marriage (Oxford 1930) i J. F. Gardner, Being a Roman Citizen (London and New York 1993). Ponadto już we wskazówkach bibliograficznych do rozdziału Persons powinno znaleźć się opracowanie B. W. Friera i T. A. J. McGinna, A Casebook on Roman Family Law (Oxford 2004), w którym zamieszczone zostały wiadomości związane z rzymskim prawem rodzinnym (Introduction to Roman Family Law, s. 3-10; Chapter I: Basic Concepts, s. 11-24; Chapter II: Marriage, s. 25-187; Chapter III: Patria Potestas, s. 189-319). Wspomniana praca jest znana autorowi, który odsyła czytelników do jej treści, ale czyni to dopiero przy okazji omawiania zagadnień z prawa spadkowego (s. 101). Paul J. du Plessis wykazał się w tym przypadku pewną niekonsekwencją.

Prawu dotyczącemu rzeczy (Things) poświęcił autor najwięcej miejsca w pracy. Swoje rozważania $w$ tej materii zaczyna od analizy zagadnień odnoszących się do własności (Property). Przedstawia podział rzeczy ze szczególnym uwzględnieniem rozróżnienia na res mancipi i res nec mancipi, charakteryzuje dominium i jego rodzaje oraz sposoby przenoszenia własności w drodze man-

"These rights (collectively known as patria potestas) were lifelong and only terminated by the death of the pater familias or the emancipation of the child".

4 „Paternal authority was lifelong and could only be terminated in one of two ways, namely either through the death of the head of the household or through the emancipation of the child". 
cipatio, in iure cessio i traditio. Zamieszcza także kilka uwag na temat służebności gruntowych i osobistych, wyjaśniając zachodzące między nimi różnice. $\mathrm{W}$ treści omawianego podrozdziału znalazły się też odniesienia do zastawu, posiadania i niektórych sposobów nabycia własności, jak zasiedzenie (usucapio), zawłaszczenie (occupatio), czy też połączenie (accessio). Tę partię opracowania zamykają informacje na temat ochrony władania rzeczami. Żałować można, że pominięta tu została całkowicie skarga negatoryjna (actio negatoria), która obok powództwa windykacyjnego (rei vindicatio) stanowiła podstawowy środek ochrony, z jakiego mógł skorzystać właściciel kwirytarny.

Podrozdział poświęcony zobowiązaniom (Obligations) to najlepsza merytorycznie część opracowania. Autor, bazując na przekazie pochodzącym z Instytucji Gaiusa $(3,88)$, omawia podział zobowiązań na te powstające ex contractu i ex delicto oraz poddaje analizie próby zdefiniowania istoty stosunku obligacyjnego w źródłach prawa rzymskiego. Następnie P. J. du Plessis dokonuje charakterystyki poszczególnych kontraktów (s. 73-85) i deliktów prawa cywilnego (s. 86-101). Swoje rozważania kończy podaniem najistotniejszych wiadomości na temat ,jakby deliktów", odpowiedzialności noksalnej, następnie odpowiedzialności za szkody majątkowe wyrządzone przez zwierzęta i tzw. przestępstw prawa pretorskiego (s. 101). Do dwóch prac dotyczących zobowiązań deliktowych wskazanych przez autora należałoby dodać jeszcze opracowanie Justinian: The Digest of Roman Law: Theft, Rapine, Damage and Insult, przekł. C. F. Kolbert (Harmondsworth 1979).

Kolejna część pracy dotyczy zagadnień prawa spadkowego (Succession). Przybliżanie problematyki dziedziczenia testamentowego autor ilustruje bardzo interesującym przykładem oświadczenia woli testatora. Nie zamieścił natomiast żadnych informacji na temat form testamentów stosowanych $\mathrm{w}$ prawie antycznego Rzymu. Podobnie jest zresztą z legatami, których rodzaje nie są nawet wymienione, a czytelnik odesłany zostaje $\mathrm{w}$ tym zakresie do lektury któregoś z podręczników prawa rzymskiego. Nieco miejsca poświęcił też P. J. du Plessis regułom odnoszącym się do dziedziczenia beztestamentowego. Wykaz sugerowanej literatury uzupełniłbym o wartościową monografię E. Champlina, Final Judgments. Duty and Emotion in Roman Wills 200 B.C. - A.D. 250 (Berkeley and Los Angeles 1991).

Ostatni rozdział Studying Roman Law wypełniają zagadnienia związane $\mathrm{z}$ przebiegiem postępowania cywilnego. Autor skoncentrował w nim swoją uwagę przede wszystkim na procesie formułkowym, wyjaśniając istotę i poszczególne części formułki.

Podsumowując spostrzeżenia na temat recenzowanej pracy, dodać należy jeszcze kilka uwag natury ogólnej. Wydaje się, iż w każdym z rozdziałów powinny znaleźć się informacje wskazujące na podstawowe źródła traktujące o omawianych instytucjach prawnych. Skoro publikacja stanowić ma sui generis przewodnik, to niech prowadzi zainteresowanych poszerzaniem swojej wie- 
dzy o prawie rzymskim głównymi szlakami, które wyznaczają właśnie źródła. Praca przeznaczona jest dla osób władających językiem angielskim, stąd podawane przez autora po każdym z rozdziałów fundamentalne pozycje bibliograficzne, mające służyć pogłębianiu wiadomości na temat prawa starożytnych Rzymian, ograniczają się do opracowań wydanych w tym języku. Podobnie jest zresztą $\mathrm{w}$ przypadku publikacji zawierających tłumaczenia źródeł prawa rzymskiego. Wykładowcy University of Edinburgh nie ma co $\mathrm{w}$ tej kwestii stawiać poważniejszych zarzutów. Paul J. du Plessis mógł jednak pokusić się o wskazanie wielotomowego dzieła S. P. Scotta, The Civil Law including the Twelve Tables, the Institutes of Gaius, the Rules of Ulpian, the Opinions of Paulus, the Enactments of Justinian, and the Constitutions of Leo (Cincinnati 1932), zawierającego tłumaczenie najważniejszych pomników prawnych starożytnych Rzymian na język angielski. Powyższa uwaga odnosi się także do Kodeksu Teodozjańskiego (s. 25), o którego przekładzie The Theodosian Code and Novels and the Sirmondian Constitutions. A translation with Commentary, Glossary, and Bibliography by C. Pharr (Princeton 1952), czytelnicy nie zostali poinformowani. Autor przy omawianiu różnych zagadnień wielokrotnie podaje łacińskie brzmienie stosownych terminów i zwrotów prawniczych. To bardzo dobrze, bo lingua Latina jest przecież nierozerwalnie związana z prawem rzymskim. Niemniej, $\mathrm{w}$ recenzowanej pracy nie znalazła się ani jedna (sic!) łacińska sentencja prawnicza. Wydaje się rzeczą naturalną, że nawet $\mathrm{w}$ opracowaniu o charakterze wprowadzającym w prawnicze arkana antycznego Rzymu powinno pojawić się przynajmniej kilka takich sformułowań. 